\title{
The Intellectual Property Provisions of the United States- Jordan Free Trade Agreement: Template or Not Template
}

Bashar H. Malkawi

Hashemite University of Jordan

The objective of this article is to examine the implications of the intellectual property provisions in the US-Jordan Free Trade Agreement (US-JO FTA) and whether they serve as a template for other Arab countries who will be concluding free trade agreements with the USA. My claim in this article is that the intellectual property part of the US-JO FTA goes beyond the World Trade Organization Agreement and cannot form the right template for the proposed US-Middle East FTA of 2013. The first section provides a brief introduction to the US-JO FTA. The second section provides a critical analysis of the FTA's protection of trademarks, copyright and patents. The third and fourth sections discuss enforcement and implementation of the intellectual property provisions of the FTA. The final section provides a conclusion regarding the intellectual property provisions of the US-JO FTA and highlights an alternative template for the proposed US-Middle East FTA.

Keywords FTA; intellectual property; Jordan; USA 


\section{Introduction}

The United States-Jordan Free Trade Agreement (US-JO FTA) was the first FTA to be concluded with an Arab country. In addition, the US-JO FTA was the second FTA between the USA and a middleincome country, after the USA and Canada expanded their FTA to include Mexico. There are several reasons that led the USA to negotiate an FTA with Jordan. Jordan was also the right candidate for an FTA economically and politically. Economically, Jordanian imports into the USA would not threaten US industries. ${ }^{1}$ The FTA could also spur on Jordan's economic growth, allowing for the possibility that it would become less dependent on foreign aid. Politically, the FTA reflects the USA's appreciation for Jordan's role in the Middle East peace process and cooperation with international counter-terrorism activities.

On June 6, 2000, King Abdullah II and then President Clinton declared that the USA and Jordan would launch negotiations for an FTA. $^{2}$ The US-JO FTA was signed in record time on October 24, 2000. The National Assembly of Jordan ratified the US-JO FTA by acclamation in May 2001. ${ }^{3}$ The US Senate approved FTA implementing legislation in September 2001. ${ }^{4}$ President Bush signed the FTA 
into a law on September 28, 2001. ${ }^{5}$ The US-JO FTA entered into force on December 17, 2001.

The US-JO FTA is comprised of a preamble, 19 articles, three annexes, joint statements, memorandums of understanding, and side letters. ${ }^{6}$ The US-JO FTA covers trade in goods and services. Moreover, the FTA covers rules of origin, e- commerce, labor, environment, and the dispute-settlement mechanism.

One of the objectives of the US-JO FTA is to emphasize the relationship between trade and intellectual property. ${ }^{7}$ The study of the intellectual property provisions of the US-JO FTA is merited because the USA uses the FTA with Jordan as a model for the bilateral trade deal that the USA concludes with other Arab countries. ${ }^{8}$ The purpose of this article is to examine the implications of these provisions on the intellectual property regime in Jordan. My claim in this article is that while the Agreement on Trade-Related Aspects of Intellectual Property Rights (TRIPS Agreement) of the World Trade Organization (WTO) sets minimum standards for the protection of intellectual property rights, the US-JO FTA requires Jordan to undertake commitments and regulatory changes that go beyond what Jordan agreed to in its accession to the WTO. In other words, the US-JO FTA represents TRIPS-Plus. I also argue that the intellectual property part of the US-JO FTA is not the right template for the proposed US-Middle East FTA of 2013.

The article proceeds as follows: the first section provides a brief introduction to the US-JO FTA. The second section provides a critical analysis of the FTA's protection of trademarks, geographical indications, copyright and related rights, patents, data exclusivity, and pharmaceuticals. The third and the fourth sections discuss enforcement and implementation of the intellectual property provisions of the FTA. Finally, the last section provides conclusions regarding the intellectual property provisions of the US-JO FTA and highlights an alternative template for the proposed US-Middle East FTA. 


\section{The intellectual property terms of the FTA}

The US-JO FTA builds on the commitments that Jordan made in acceding to the WTO. Article 4 of the US-JO FTA occupies five pages out of 20 pages of the FTA and is the longest article in the whole text of the FTA. The US-JO FTA defines the nature and the scope of intellectual property rights. ${ }^{9}$ The US-JO FTA protects copyrights, trademarks, and patents.

The US-JO FTA encourages each party to make its best effort in ratifying or acceding to the Patent Cooperation Treaty of 1984 and the 1989 Madrid agreement concerning the international registration of marks. ${ }^{10}$ The US-JO FTA provides for national treatment. In other words, the FTA requires each party to provide the nationals of the other party treatment no less favorable than it gives to its own nationals with respect to the protection and enjoyment of all intellectual property rights. ${ }^{11}$ Jordan promulgated a new regulation in which the censorship fees for audio-visual carriers were increased considerably. ${ }^{12}$ These censorship fees may 
violate Jordan's national treatment obligation under the US-JO FTA. The follow- ing section gives a step-by-step account of the intellectual property provisions of the US-JO FTA.

Trademarks and geographical indications

The FTA specifically addresses trademarks and geographical indications (GIs). Trademarks include service marks, and collective marks and certification marks. ${ }^{13}$ A collective mark is a species of trademark. Collective marks belong to associations, cooperatives, or unions used to distinguish goods in respect of origin or material. Examples of collective marks include marks of bakers cooperatives or optician associations. A collective mark does not indicate a single entity that sells or makes the goods but rather indicates that such goods come from a member of the group that is exercising control over the use of the mark. A certification mark is a mark to "certify" the quality or characteristics of goods. A certification mark is a guarantee of compliance with uniform standards, whereas a collective mark serves as a characteristic of self-identification. Jordan's Trademarks Law of 1999 does not make reference to collective service marks. ${ }^{14}$ To comply with the FTA, Jordan may need to consider amendments to its Trademarks Law of 1999 so as to cover collective marks appropriately. In this way, the law can avoid any confusion between trademarks, collective marks, and certification marks.

Gls are indications that identify the geographical origin of a good where a given

quality, reputation, or other characteristic of the good is essentially attributable to its geographical origin. Examples of Gls include Roquefort and Champagne. According to the FTA, trademarks may include Gls. ${ }^{15}$ Thus, the FTA merges Gls and trademarks, meaning that a GI could be trademarked. ${ }^{16}$ The USA exported its complex intellectual property statutes and judicial decisions into the language of the US-JO FTA. The language in the FTA affirms the USA opposition for the protection of GIs. The USA does not have a geographical indication law, but rather it protects geographical indication through trademark law. ${ }^{17}$ Examples of Gls in the USA that are protected by trademark law include Chablis, Darjeeling tea, Florida citrus, Vidalia onions, Maine lobsters, and 
Budweiser beer.

The US-JO FTA obligates each party to afford owners of registered trade- marks the exclusive right to prevent any party from using an "identical or similar" mark for a "related" good or service for which the trademark is used. ${ }^{18}$ The US-JO FTA also protects against the use of a well-known mark. ${ }^{19}$ The protection of wellknown marks is an area of concern in Jordan. In the past, due to the lack of explicit provisions preventing the registration of well-known marks, many local Jordanian companies filed applications to register well-known marks under their own names. ${ }^{20}$ Many foreign owners of well-known trademarks had to litigate in Jordan because of the trademark registrations by Jordanian persons. For example, Shaheen Interna- tional Corporation Co. filed an application to register the mark PILLSBURY in its name in Jordan. ${ }^{21}$ In another example, Hani AlQudsi \& Partners, a Jordanian company, filed a trademark application to register the mark "7ELEVEN" in class 
16. ${ }^{22}$ Now, well-known marks are expressly protected, and the USJO FTA affirms such protection.

The FTA addresses the non-recording of a trademark license. ${ }^{23}$ The FTA stipulates that the non-recording of a license does not affect the validity of the registration of a trademark or protection of rights for that trademark. ${ }^{24}$ If a trademark holder licenses the use of his mark to a licensee, any use by the licensee may constitute a use by the holder and any subsequent rights would accrue to the holder. The Jordanian Trademarks Law of 1999 allows the rights associated with a mark to be licensed. However, the right to license a trademark remains subject to some scrutiny and constraints. For example, the license must be made in a notarized contract and recorded with the Trademark Office. ${ }^{25}$ The Trademarks Law of 199 must be amended so as to bring Jordan into full conformity with its FTA commitments.

\section{Copyright and related rights}

The US-JO FTA addresses how copyrights operate in cyberspace and are protected from Internet piracy. The US-JO FTA incorporates by reference article 1(4) of the World Intellectual Property Organization (WIPO) Copyright Treaty (WCT), the "agreed statement" of the WCT, and articles 7 and 11 of the WIPO Performances and Phonograms Treaty (WPPT). ${ }^{26}$ The US-JO FTA provides copyright holders with the exclusive right to prohibit the availability of their works. The prohibition applies to importation and all reproductions whether it is permanent or temporary, which can include temporary storage in a computer memory. ${ }^{27}$ The traditional right of reproduction continues to apply in the digital environment. However, it has many implications. The exclusive right of prohibition restricts the ability of Jordan to issue compulsory licensing. The FTA appears to be locking Jordan into treating temporary copies as reproductions within the scope of the reproduction right. Thus, telecommunications companies and Internet providers may be subject to infringe- ment liability for the copying that is inherent in the use of computer networks. Despite the fact that the "agreed statement" accompanying the WCT (the equiva- lent of legislative history) makes 
it clear that the reproduction right includes the right to make digital copies, the "agreed statement" may be used to clarify that certain copying, e.g. for temporary digital storage, is permitted.

The US-JO FTA requires parties to provide performers and sound-recording

producers with an exclusive right to communicate and broadcast to the public of their phonograms by wired or wireless means. ${ }^{28}$ The FTA parties, however, have the flexibility in establishing exceptions to the exclusive right of performers and producers of phonograms. For example, a party may provide exceptions for analog transmissions and non-subscription over-the-air programming. Moreover, the FTA parties may provide, through legislation, licenses for non-interactive services such as a pay service or subscription. Previously, Jordan's Copyright Law provides producers of sound recordings with the right of "making available" their phono- 
grams. Jordan's Copyright Law was amended to incorporate the right of "exclu- sivity" of producers of phonograms. ${ }^{29}$

The US-JO FTA covers anti-circumvention measures by prohibiting the circumvention of effective technological measures that protect copyright. ${ }^{30}$ For example, under the FTA it is illegal to disable a technology that is designed to prevent burning of the content of a CD. The source of the FTA language is the US Digital Millennium Copyright Act of 1998, which protects intellectual property in the digital environment. ${ }^{31}$ The FTA requires each party to prohibit both civilly and criminally the manufacture, importation, or circulation of any technology, device, or service that is designed, produced, performed, or marketed for engaging in such prohibited conduct or has only limited commercially significant purposes or uses other than enabling or facilitating such conduct. ${ }^{32}$ As a result of the FTA anti- circumvention provisions, manufacturers may face uncertainty as to whether a device is "used" for commercial purposes or to circumvent technological measures. The current Jordanian Copyright Law prohibits circumventing effective technological measures. ${ }^{33}$ The Jordanian Copyright Law should be amended to cover expressly all forms of "circulation" of the technological device, to prohibit not only the technological device but also "component parts", and to prohibit activity "that has only a limited commercially significant purpose or use other than enabling of facilitating such conduct".

The US-JO FTA deals with transfer of economic rights. ${ }^{34}$ It recognizes the

transfer of economic rights held by a contractual agreement or otherwise. The US-JO FTA requires that the parties enact appropriate laws, regulations, or other measures that provide that all government agencies use "only" legitimate software and manage government software use. ${ }^{35}$ The purpose of requiring government agencies to use legitimate computer software is to set an example for private parties, which is a step towards combating copyright piracy. Neither the Jordanian Copy- right Law nor any regulation or decree addresses the FTA requirement by mandating that all government agencies in Jordan must use legitimate software, and must adequately manage government software usage.

The FTA provides exceptions and limitations to the exclusive 
rights of copy- right holders. Any exception, however, must be confined to certain cases that do not conflict with the normal exploitation of the work and do not unreasonably prejudice the legitimate interests of the right holder. ${ }^{36}$ An example of an exception to the exclusive rights of copyright holders is the creation of back-up copies of a computer program. WTO panels have interpreted the exceptions to copyright on the basis of a three-step test. ${ }^{37}$ The Jordanian Copyright Law should narrow any exceptions using the three-step test developed by the WTO panel decision. Thus, WTO panel decisions may provide guidance as to how a US or Jordanian citizen can act within the exceptions and limitations of the FTA. Moreover, the Jordanian Copyright Law must confirm that it would not permit anthologizing "full" articles to create books or photocopying "entire" books because this anthologizing and copying would interfere with the normal exploitation of the work. 


\section{Patents}

The US-JO FTA determines the conditions for patentability. Any invention in any field of technology is patentable as long as the invention is new, involves an inventive step, and is capable of industrial application. ${ }^{38}$ In addition, the inventor must disclose the information pertinent to the creation of his invention so that others skilled in the art can carry out the invention. ${ }^{39}$

The US-JO FTA excludes from patentability any invention whose exclusion is necessary to protect ordre public, morality, human, animal or plant life or health, or to avoid serious prejudice to the environment. ${ }^{40}$ In addition, the FTA excludes from patentability diagnostic, therapeutic, and surgical methods for the treatment of humans or animals. ${ }^{41}$ Contrary to the TRIPS Agreement, the FTA does not exclude from patentability life forms, which is an issue of tremendous importance for US biotechnology companies. ${ }^{42}$ The US-JO FTA entertains broader subject matter patentability than the TRIPS Agreement.

The US-JO FTA's Memorandum of Understanding on Issues Related to the Protection of Intellectual Property Rights expands the patentability provisions to include business methods and computerrelated inventions. ${ }^{43}$ The issue of patenting business methods is derived from USA laws and practices. In 1998, the USA introduced the concept of patenting business methods. ${ }^{44}$ On several occasions, USA courts granted patents for methods of doing business. ${ }^{45}$ Under the FTA, anything under the sun made by man could be patentable. The US-JO FTA provisions relating to the patentability of business methods were drafted to meet the interests of the USA.

The US-JO FTA tightens the marketing approval process by calling for the need to notify the identity of any third party requesting marketing approval effective during the term of the patent. ${ }^{46}$ The US-JO FTA also addresses compul- sory licensing. ${ }^{47}$ It allows the issuance of compulsory licensing in three cases only: to remedy a practice determined to be anti-competitive; for public non-commercial use or national emergency or other circumstances of extreme emergency; and if there is a failure to meet working requirements. ${ }^{48}$ In contrast, the TRIPS Agreement left open the grounds for issuing compulsory licensing. ${ }^{49}$ The compulsory licensing 
language of the US-JO FTA reflects US policy. The USA treats compulsory licensing as an exceptional policy tool to be used only in limited cases rather than a standard part of the intellectual property regime.

Data exclusivity and pharmaceuticals

The US-JO FTA requires that Jordan protects confidential clinical test data in marketing approval applications from misappropriation. ${ }^{50}$ The FTA does not limit the protection that foreign companies receive for their clinical test data of pharmaceuticals. Data exclusivity, however, can delay the introduction of generic competition for life-saving drugs for example. Under the FTA, drug-regulatory authorities will not allow a drug originator's registration files to be used to register a therapeutically equivalent generic variation of a medicine for a fixed period of time. 
The FTA effectively extends monopolies by drug originators and affects access to medicines. Generics will effectively be barred from entering the market, even if patent terms have expired and even if a country has issued a compulsory license for a product that is on patent, until the monopolies on the use of the data expire.

The US-JO FTA went further to limit competition, and prevented Jordanian companies from using new innovations for different uses. The US-JO FTA thus added another clause by stating that protection for new chemical entities will also include protection for new uses of old chemical entities for a period of 3 years. ${ }^{51}$ The 3-year period for the protection of new uses of old chemical entities will be added to the protection period already given for registering a new brand.

The US-JO FTA extends the patent term for pharmaceutical products. ${ }^{52}$ Extending the patent term vindicates the expectations of inventors who did not receive a 20-year term at the time the patent application was first filed. Extending the patent term applies specifically to pharmaceutical products that undergo human and animal tests to ensure their safety for use before being granted marketing approval. Whether to use patent extension or not will depend on the existence of an inefficient/efficient drug-approval system in Jordan.

The US-JO FTA mandates that Jordan "makes available" an extension of the patent term. This language indicates that patent term extensions were not intended to be mandatory. Jordan is obliged to provide access to an extension by giving the inventor the chance to file an application for an extension. The FTA does not determine the period of extension of a patent term. However, textually, the use of the term an "extension" in a singular format can be interpreted to mean that an extension of the patent term is allowed only once. 


\section{Enforcement of intellectual property rights}

The US-JO FTA includes provisions governing enforcement of intellectual prop- erty rights, including the availability of injunctions, damages, and other remedial measures. ${ }^{53}$ In cases of a known infringement of trademark, copyright, and related rights, judicial authorities can order the infringer to pay the right holder "adequate damages". ${ }^{54}$ The US-JO FTA is a more detailed numeration of the TRIPS Agreement. The US-JO FTA makes use of a mathematical formula to compute how much injury the right holder sustained in order to calculate the amount of damages. An injury determination is based on the value of the infringed-upon item according to the suggested retail price (SRP) of the legitimate product or other equivalent measures established by the right holder for valuing authorized goods. ${ }^{55}$ Using the SRP will increase the value of the product and thus increase the amount of damages awarded beyond what could have been awarded if the actual retail price had been used. The Jordanian Copyright Law refers to "fair compensation" only. ${ }^{56}$ Moreover, the Jordanian Copyright Law states that "adjudicated compensation shall be considered a privileged debt with respect to the net price of the sale of the objects which were used to infringe the rights of the copyright holder and the sum of 
money seized in the lawsuit". Thus, the Jordanian Copyright Law calculates damages on the basis of the infringer's profits plus amounts seized from the infringer. Such a calculation may not be adequate to compensate the right holder. The Jordanian Copyright Law falls short of the US-JO FTA and therefore must be amended.

The US-JO FTA imposes statutory fines on infringers. ${ }^{57}$ The US-JO FTA requires Jordan to increase its statutory-based fines sufficiently to deter future acts of infringement by removing the monetary incentive of infringers. After Jordan modified its copyright law, statutory fines were doubled, from Jordanian Dinar 3,000 (US\$4,235) to Jordanian Dinar 6,000 (US\$8,469). ${ }^{58}$ In the future, these statutory fines may be increased to Jordanian Dinar 10,000 (US\$14,115). The test that the US-JO FTA uses is whether statutory fines are sufficient to deter future acts of infringement by removing the monetary incentive of infringers.

Furthermore, the FTA requires authorities to seize all suspected pirated copy- right and counterfeit goods, related implements that are used predominantly to commit the offense, and documentary evidence of infringement. ${ }^{59}$ The Jordanian Copyright Law does not have an express provision for seizure of documentary evidence. With respect to criminal actions and border measures, the FTA requires national authorities to act ex officio, i.e. upon their own initiative, without the need for a private party or right holder to lodge a formal complaint. ${ }^{60}$ This allows rights holders to protect their rights while avoiding time-consuming legal proceedings. The Jordanian Copyright Law does not include a provision that authorizes ex officio action.

The US-JO FTA establishes a rebuttable presumption that the author, producer, performer, or publisher of a work whose name appears on the work is the person entitled to bring a civil infringement case to protect his copyright. ${ }^{61}$ The Berne Convention for the Protection of Literary and Artistic Works (Berne Convention) requires presumption as to authorship only, while the US-JO FTA goes further to require presumptions as to ownership, subsistence of copyrighted works, performances, and phonograms. The Jordanian Copyright Law was amended to provide the FTA's presumptions of ownership and subsistence of copyright. ${ }^{62}$ Therefore, the Jordanian Copyright Law fulfills the US-JO FTA 
requirements.

The FTA changes the conventional definition of piracy. It defines willful copyright piracy on a commercial scale as involving significant willful infringement that has no direct or indirect motivation of financial gain. ${ }^{63}$ Piracy is a term that has no uniform definition. While it is most often used to refer to an egregious infringement of copyright, it is also used to refer to the intentional and systematic infringement with the purpose of profitmaximization. ${ }^{64}$ According to the FTA, an infringer with no direct or indirect financial motive is liable for copyright piracy, similar to a willful infringer motivated by financial gain. Since the Jordanian Copyright Law criminalizes the exercise of exclusive rights without authorization, ${ }^{65}$ it could be interpreted as criminalization of infringers who infringe without direct or 
indirect motivation of financial gain. However, it would better if the Jordanian Copyright Law were amended to make it clear that there is no need for a profit motive in order for a defendant to be liable for infringement.

\section{Implementation}

The US-JO FTA entered into force on December 17, 2001. The US-JO FTA sets out a timetable for Jordan to comply with its intellectual property obligations. Jordan is required to implement articles 4.1.(c), 4.1(d), and 4.10-4.16 of the US-JO FTA within 2 years from the date the FTA enters into force. ${ }^{66}$ In other words, Jordan should have complied with these obligations on December 17, 2003. Jordan should also have complied with article $4.1(\mathrm{~b})$ of the US-JO FTA within 6 months from the effective date of the FTA, i.e. June 17, 2002. The FTA further mandates that Jordan shall meet the enforcement obligations in articles $4.24-4.28$ of the US-JO FTA on December 17, 2004. Jordan should promptly protect undisclosed data or tests for purposes of marketing approval of pharmaceutical or agricultural chemical products. Finally, Jordan needed to accede to WCT and WPPT by December 17, 2003, which is a deadline that it has missed. However, Jordan acceded to the WCT on April 27, 2004 and to the WPPT on May 24, 2004. ${ }^{67}$

The transitional period granted to Jordan to implement its intellectual property obligations is a form of special and differential treatment. However, the TRIPS Agreement allows developing countries special treatment with respect to fulfilling their obligations; thus, similar provisions in the US-JO FTA are not unique. The US-JO FTA creates a vacuum because it does not determine a transitional period for compliance with the Memorandum of Understanding on Issues Related to the Protection of Intellectual Property Rights, which includes provisions related to the patentability of business methods.

The intellectual property provisions of the US-JO FTA require Jordan to modify its laws and regulations. The USA will not hesitate to invoke the FTA's dispute-settlement mechanism if Jordan does not live up to its obligations. ${ }^{68}$ The threat of using the disputesettlement mechanism on the part of the USA should not be taken 
lightly because it may lead to suspension of the trade benefits that Jordan is currently enjoying under FTA in the form of duty-free access to the US market.

\section{Conclusion}

The intellectual property provisions of the US-JO FTA are one-sided. They were drafted to protect US intellectual property rights. In great parts, the intellectual property part of the US-JO FTA reflects the laws and views of the USA: for example, the anti-circumvention of technological measures designed to protect intellectual property rights, patenting life forms and business methods, and limiting the cases that justify invoking compulsory licensing, just to list few. The FTA represents a homogenization of intellectual property laws between the USA and Jordan. This harmonization of standards may not be a desirable objective. It is 
preferable to have separate policy instruments for each party rather than one single policy instrument covering both parties.

Although the intellectual property provisions of the US-JO FTA in many instances refer to "The Parties" or "Each Party", the reference is directed to Jordan, which has to implement these provisions. The FTA parties entered into asymme- trical commitments.

The intellectual property provisions of the US-JO FTA require Jordan to undertake commitments and regulatory changes that go beyond what Jordan agreed to in its accession to the WTO. The intellectual property part of the US-JO FTA is a WTO-Plus agreement. There are many exceptions to the intellectual property rights codified in the TRIPS Agreement. In contrast, the intellectual property provisions of the US-JO FTA include only a few exceptions.

The traditional "North-South" division, with developed countries favoring strong intellectual property protection and developing countries favoring more relaxed protection, will become more apparent in future FTAs concluded between the USA and Arab countries. Provisions covering intellectual property in the digital media would feature as standard clauses in future FTAs brokered by the USA with Arab countries such as Kuwait, Egypt, Lebanon, and Saudi Arabia. For example, future FTAs between the USA and Arab countries would protect rights manage- ment information by prohibiting the deliberate alteration or deletion of electronic rights management information-information that identifies a work, its author, performer, or owner, and the terms and conditions for its use. Future FTAs between the USA and Arab countries would also protect domain names and would require Arab countries to implement a dispute-resolution procedure based on the principles of the Uniform Domain Name Dispute Resolution Policy. These FTAs would require Arab countries to operate a Who is-style database that would provide the public with a reliable and accurate database of contact information for domain- name registrants. Future FTAs would require Arab countries to criminalize the manufacture and distribution of devices that are primarily used in decoding an encrypted program-carrying satellite signal without authorization. Internet service providers (ISPs) will be treated in future trade 
agreements, which provide legal incentives for ISPs to cooperate with copyright owners in deterring the unauthor- ized storage and transmission of copyrighted works. Future trade agreements between the USA and Arab countries may ban importing or reimporting prescrip- tion drugs into the USA from those countries.

The experience and lessons learned from the intellectual property provisions of

the US-JO FTA must serve as a base for a new approach for the proposed US-Middle East FTA. The intellectual property part of the US-JO FTA may not be the best template. The intellectual property part of the US-JO FTA is not one-size-fits-all. Future FTAs between the USA and Arab countries must address communal rights, such as traditional knowledge or folklore expressions. Future trade agreements should emphasize cultural protection to guard Arab countries' domestic audio-visual sector culture from foreign films, music, and television 
programming. Future trade agreements must contain provisions relating to the transfer and dissemination of technology. These FTAs should not focus only on creativity and innovation but must refer to the transfer and dissemination of technology or the interest of the public. These FTAs, should link intellectual property rights with the transfer of technology and investment. Some of the intellectual property provisions in the US-JO FTA, such as patenting life forms and business methods, are setting a dangerous precedent, and they must be lifted from the table when Arab countries negotiate future trade deals.

\section{Acknowledgments}

I am indebted to Professor David Gantz at the University of Arizona for his advice and comments on earlier drafts. I also thank Donna Butler for her editorial help.

\section{About the Author}

Bashar H. Malkawi, is Assistant Professor of international trade law at the Hashemite University of Jordan. He holds an S. J. D. in International Trade Law from the American University, Washington College of Law, and an L.L.M. in International Trade Law from the University of Arizona; e-mail: bmalkawi@ gmail.com 


\section{Notes}

1 A study conducted by the Office of Economics and the Office of Industries of the US International Trade Commission found that Jordan's exports to the USA would not have a measurable impact on US industries, employment, and production. For one sector, textiles and apparels, a likely rise in US imports of apparel is expected to have an effect, but this effect is negligible. See US International Trade Commission, Economic Impact on the United States of a US-Jordan Free Trade Agreement, 5-1 Pub. No. 3340, September 2000.

2 See G.G. Yerkey, US, Jordan make "substantial" progress in talks on free trade agreement, USTR says, International Trade Reporter (BNA), 17 (August 3, 2000), 1224 (stating agreement to initiate negotiations was announced by US officials following a meeting between President Clinton and King Abdullah on June 6 in Washington, DC).

3 See Royal Decree, Official Gazette No. 4486, (April 1, 2001), p. 1664.

4 See the United States-Jordan Free Trade Agreement Free Trade Area Implementation Act, S.2603, 107th Congress (2001).

5 See United States-Jordan Free Trade Agreement Implementation Act, Pubic Law, 107-143, Statutes at Large, 115 (2001) 243.

6 See United States (US)-Jordan: Agreement Between The United States of America and the Hashemite Kingdom of Jordan on The Establishment of a Free Trade Area, International Legal Materials, 41 (October 24, 2000), 63.

7 The preamble of the US-JO FTA emphasizes the desire of both parties to foster creativity and innovation and promote trade in goods and services that are subjects of intellectual property rights. Ibid., preamble. 
8 See G.G. Yerkey, President Bush lays out broad plan for regional FTA with Middle East by 2013, International Trade Reporter (BNA), 20 (May 15, 2003), 856 (the USA will use a "building-block" approach that requires, as a first step, a Middle East country to accede to the WTO or concluding Trade and Investment Framework Agreement(s) (TIFA). Afterwards, the USA will negotiate FTAs with individual countries. The USA will use the US-JO FTA as a model for these FTAs. Finally, preferably before 2013, a critical mass of bilateral FTAs would come together to form the broader US-Middle East FTA).

9 Each party to the FTA will have to give effect, at minimum, to the provisions of article 4. See US-JO FTA, supra n. 6, article 4.1.

10 Ibid., article 4.2. Jordan is not a party to the Patent Cooperation Treaty (PCT) or the Madrid protocol, while the USA is party to both of them. Since all intellectual property rights are territorial, an inventor, for example, has to file a patent application in every country to protect its invention. To ease this burdensome process, WIPO administers the PCT for the filing, searching, publication, and examination of international applications. The PCT makes it easier to obtain patents in other countries by providing for the filing of one international application, which may be subsequently prosecuted in the different designated national or regional offices of countries party to the PCT. However, the ultimate decision to grant a patent is left to those designated offices. Thus, the purpose of the PCT is to facilitate the filing of patent application. See D. Pruzin, WIPO members agree to new filing fees under treaty, reduced electronic filer fees, International Trade Reporter (BNA), 20 (October 9, 2003), 1649. By the same token, WIPO administers an international registration of trademarks through what is known as the Madrid system. It is composed of two treaties that complement each other. These two treaties are the Madrid agreement of 1891and the Madrid protocol of 1989. The Madrid system works in the same manner as the PCT by filing an international application for the registration of a trademark, but the ultimate decision is left to the designated countries whether to afford protection to a 
trademark or not. To apply for international registration under the protocol, an applicant must be a national, or domiciled, or have an effective and real business or commercial establishment in one of the countries that are members of the protocol. The registration of a trademark in one of the members serves as the basis of an international application (known as the basic application). The international application must be submitted through the trademark office of the basic application. Then, after verification, the international application is submitted to the International Bureau of WIPO. The International Bureau then examines the international application to determine whether the filing requirements and fees have been fulfilled. If the application is regular, then the International Bureau registers the mark and publishes it in the WIPO Gazette of International Marks. Every designated country in the international application will examine the application under its own laws. See PTO Issues Rules, Amendments to implement Madrid Protocol Act, International Trade Reporter (BNA), 20 (October 9, 2003), 1649.

11 See US-JO FTA, supra n. 6, article 4.3.

12 See Censorship Regulation for Audio-Visuals No. 63 of 2004, articles 12 and 13, amended by the Regulation No. (38) of 2005, Official Gazette No. 1992 (March 22, 2005).

13 The FTA parties are not obliged to treat certification marks as a separate category in their national laws, as long as such marks are protected. See US-JO FTA, supra n. 6, article 4.6. 
14 See Trademarks Law No. (33) of 1952, amended by the Law No. (34) of 1999, Official Gazette No. 4389 (November 1, 1999).

$15 \mathrm{~A} \mathrm{Gl}$ will be considered a trademark if it consists of any sign, or any combination of signs, capable of identifying a good or service as originating in the territory of a party, or a region or locality in that territory, where a given quality, reputation, or other characteristic of the good or service is essentially attributable to its geographical origin. See US-JO FTA, supra n. 6, article 4.6. 16 Under the TRIPS Agreement, there is a distinction between the trademarks and GIs, in that a trademark indicates a single source of goods while Gls can indicate multiple sources of goods, as long as they come from the same geographical origin. See J.R. Renaud, Can't get there from here: how NAFTA and GATT have reduced protection for geographical trademarks, Brooklyn Journal of International Law, 26 (2001), 1097, at 1115.

17 The USA did not historically place cultural or economic importance on Gls: many Gls developed as generic terms when early European immigrants came to the USA and brought vine to plant in the USA. The USA is hostile to Gls because they provide protection indefinitely, and it believes that no one can obtain an exclusive right to use geographic name to preclude others from using the geographical term. See S.D. Goldberg, Who will raise the white flag? The battle between the United States and the European Union over the protection of geographical indications, University of Pennsylvania Journal of International Economic Law, 22 (2001), 107, at 136.

18 See US-JO FTA, supra n. 6, article 4.7.

19 Ibid., 4.8.

20 See A.H. Khoury, The development of modern trademark legislation and protection in Arab countries of the Middle East, The Transnational Lawyer, 16 (2003), 249, at 269 and 321.

21 However, the Pillsbury company filed an opposition contesting such registration and contending that its PILLSBURY mark is a well-known mark used to market its ready- made dough and bakery products worldwide including in Jordan. As a result, a settlement was reached, whereby Shaheen agreed to assign the trademark registration over to the Pillsbury company in return 
for the latter's agreement not to initiate a legal action for damages or compensation. Ibid., at 321.

22 The Southland Corporation, a US corporation, filed an opposition claiming that the Jordanian applicant was not entitled to such registration since it uses and owns registrations of the mark "7ELEVEN" in various countries worldwide. The Southland Corporation prevailed in its opposition not so much on the merits but rather on points of procedure. The Jordanian company did not submit its response to the opposition on time. Ibid.

23 Non-recordal is a problem area in the ongoing negotiations of amending the Trademark Law Treaty of 1994 by WIPO membership.

24 See US-JO FTA, supra n. 6, article 4.9.

25 See Trademarks Law No. (33), supra n. 14, articles 26(2)-(3). 26 See US-JO FTA, supra n. 6, article 4.10. Both treaties, WCT and WPPT of 1996, have no parallel in TRIPS. It should come as no surprise that these two treaties are absent from TRIPS since they were concluded in 1996, 2 years after TRIPS came into existence. WIPO's Diplomatic Conference on Certain Copyright and Neighboring Rights 
Questions convened in 1996. At the end of the Conference, participants reached a consensus on treaties dealing with copyright and performances and phonograms. The treaties were created in response to the arrival of the digital age and are known as the "Internet treaties". See S.A. Mort, The WTO, WIPO \& the Internet: confounding the borders of copyright and neighboring rights, Fordham Intellectual Property Media and Entertainment Law Journal, 8 (1997), 173, at 176 and 195.

27 See US-JO FTA, supra n. 6, articles 4.10 and 4.11.

28 Ibid., article 4.12.

29 See Provisional Copyright Law No. (52) of 2001, amended by the Law No. (9) of 2005, article 23, Official Gazette No. 1097 (February 21, 2005).

30 See US-JO FTA, supra n. 6, article 4.13.

31 See US Digital Millennium Copyright Act of 1998, 17 USCA \%o 1201 (b) (2003). The Digital Millennium Copyright Act of 1998 makes exceptions from the anticircumvention measures language for nonprofit libraries, reverse engineering to make software interoperable, encryption research, protecting personal information, security testing, and preventing minor access to inappropriate materials. These exceptions are not included in the US-JO FTA. The FTA incorporates article 11 of the WCT and article 18 of the WPPT by reference. However, the WCT and WPPT provide a general obligation to protect adequately against circumvention of technological measures.

32 Article 4.13 of the US-JO FTA prohibits "manufacture" of a device that is designed to circumvent technological measure. This language could be called an "anti-production" provision. Moreover, article 4.13 of the FTA prohibits "importation" or "circulation" of such a device. This is could be called "anticommercial activity" provision. Moreover, article 4.13 of the FTA distinguishes between two cases. The first case is the prohibition against a device that is "designed", "produced", "performed", or "marketed" for engaging in such prohibited activity. In other words, the primary purpose of the device is to circumvent a technological measure. The second case is where the device has "only" a limited commercial significance purpose or use other 
than enabling or facilitating the prohibited conduct. The second case requires weighing up whether the device has a significant commercial purpose, other than to circumvent technological measures.

33 See Provisional Copyright Law No. (52) supra n. 29, article 55. 34 See US-JO FTA, supra n. 6, article 4.14.

35 Ibid., article 4.15.

36 Ibid., article 4.16. The FTA language is identical to article 10 of the WCT, article 16 of the WPPT, and article 13 of TRIPS.

37 The WTO panel in the US-Section 110(5) of the Copyright Act case defined article 13 of the TRIPS Agreement as an exception that articulates the scope of the so-called "minor exceptions" doctrine. The panel further delineated that limitations or exceptions to exclusive rights can only be made if three conditions are met: (1) the limitations or exceptions are confined to certain special cases; (2) they do not conflict with a normal exploitation of the work; and (3) they do not unreasonably prejudice the legitimate interests of the right holder. See United States-Section 110(5) of the US Copyright Act, June 15, 2000, WTO Doc. No. WT/DS160/R, paragraph 6.58.

38 See US-JO FTA, supra n. 6, article 4.17.

39 Ibid., 4.21. The US-JO FTA stipulates that if it is not possible to provide a "sufficient written description" of the invention to enable others skilled in the art to carry out the 
invention, the USA or Jordan shall require a deposit with an international depository authority as defined in the Budapest Treaty on the International Recognition of the Deposit of Microorganism for the Purposes of Patent Procedure of 1980. The Budapest Treaty is primarily concerned with procedural matters associated with microorganism- related inventions and leaves substantive rules to national laws. The treaty provides for the establishment of international depository authorities (IDAs) to collect cultures.

Under the regulations of the Budapest Treaty, samples of biological materials deposited with an IDA may be furnished to interested industrial property offices, the depositor, or those authorized by the depositor and parties who are legally entitled to obtain a sample. A single deposit with an IDA satisfies the deposit requirement in all countries that are members of the Budapest Treaty. In addition, the application must prove that the sample and any information accompanying or resulting from it will be used only for the purposes of the said patent procedure. See R.I. Gordon, Facilitating the exchange of scientific information: Institut Pasteur v United States, Boston University International Law Journal, 6 (1988), 179, at 207 and 212.

40 See US-FTA, supra n. 6, article

4.18(a). 41 Ibid., article 4.18(b).

42 The TRIPS Agreement in article 27.3.(b) excludes from patentability plants and animals, and biological processes for the production of plants or animals. The USA proposed, in a document submitted to the WTO in preparation for the Seattle Ministerial Conference of 1999, that the TRIPS Council should initiate a work to see whether it is desirable to modify the TRIPS Agreement to eliminate the exclusion from patentability of plants and animals. See Preparation for the 1999 Ministerial Conference, November 19, 1999, WTO Doc. No. WT/GC/W/115. In 1988, the US Patent and Trademark Office issued a patent covering an animal, known as Transgenic Mouse. Ever since, thousands of gene-related patent applications have been filed with the US Patent and Trademark Office. On the other hand, the 
EC's Biotechnology Directive considers certain subject matters to be per se unpatentable including processes for modifying the genetic identity of animals that are likely to cause them suffering without any substantial medical benefit to humans or animals, and also animals resulting from such processes. See L.B. Andrews, The gene patent dilemma: balancing commercial incentives with health needs, Houston Journal of Health Law and Policy, 2 (2002), 65 (publication page references not available). 43 Paragraph 5 of the memorandum reads "Jordan shall take all steps necessary to clarify

that the exclusion from patent protection of 'mathematical methods' in article 4(B) of Jordan's Patent Law does not include such 'methods' as business methods or computer- related inventions". See Memorandum of Understanding on Issues Related to the Protection of Intellectual Property Rights, at hhttp://www.ustr.gov/regions/eu-med/ middleeast/memopro.pdfi.

44 A business method can be defined as a method of administering, managing, or otherwise operating an enterprise or organization. The term "business method" means:

(1) a method of
(A) administering, managing, or otherwise operating an enterprise or organization, including a technique used in doing or conducting business; or
(B) processing financial data; 
(2) any technique used in athletics, instruction, or personal skills; and

(3) any computer-assisted implementation of a method described in paragraph (1) or a technique described in paragraph (2). See the Business Method Patent Improvement Bill of 2000, 2000 H.R. 5364, 106th Cong., 2d Sess. (2000).

45 In a case that involved a method for processing financial data in a hub-and-spoke system for mutual funds accounting and administration, the Court of Appeals for the Federal Circuit held that such a method is not excluded from patentability. See State Street Bank \& Trust Co. v Signature Financial Group, Inc, 149 F.3d 1368 (Fed. Cir. 1998). In another case, Amazon.com and other inventors filed with the US Patent and Trademark Office a patent application for a method and system for placing an order to purchase an item via the Internet, known as the "1-click" method. In 1999, Amazon.com filed

a suit against Barnesandnoble.com, claiming that Barnesandnoble.com's "Express Lane" ordering feature infringed Amazon.com's patent. Amazon.com obtained a preliminary injunction against the use of its business method by barnesandnoble.com. In 2001, however, the Court of Appeals for the Federal Circuit vacated the preliminary injunction and remanded the case, ruling that all the necessary prerequisites for granting a preliminary injunction were presently lacking. The Court of Appeals decided that the District Court erred by not recognizing prior art reference. For example, CompuServe's Trend Service, which allowed CompuServe's subscribers to purchase stock charts, appeared to use a single-action ordering technology. Another prior art reference, a book, copyrighted in 1996 and entitled Creating the Virtual Store addressed the singleaction method. See S.A. Mota, Internet business method patents - the federal circuit vacates the preliminary injunction in Amazon.com $v$ Barnesandnoble.com, The John Marshall Journal of Computer and Information Law, 19 (2001), 523, at 528. In 2002, Amazon and Barns and Noble eventually reached a confidential 
settlement. See R.C. Scheinfeld and J.D. Sullivan, Internet-related patents: are they paying off?, New York Law Journal (December 10, 2002), 5.

46 See US-JO FTA, supra n. 6, article 4.19.

47 Ibid., article 4.20.

48 The US-JO FTA does not define a national emergency for the purpose of invoking compulsory licensing. The FTA considers importation of the patented product as working. See P. Champ and A. Attaran, Patent rights and local working under the WTO TRIPS Agreement: an analysis of the US-Brazil patent dispute, Yale Journal of International Law, 27 (2002), 365, at 366 and 369 (the USA sought in TRIPS negotiations to bar any possible obligation or remedy there might be for a patentee's failure to work locally. The USA also sought to restrict compulsory licensing to national emergencies and anti-competitive abuses).

49 Article 31 of the TRIPS Agreement sets specific conditions for granting compulsory licensing but does not list or define the cases where a license may be granted. Subsequent to the TRIPs Agreement, WTO members adopted a Declaration on the TRIPS Agreement and Public Health, which grants countries the right to issue compulsory licenses and the freedom to determine the grounds upon which such licenses are issued. As party to the USJO FTA., Jordan cannot benefit from the Declaration because it locked in the cases in which a compulsory license may be granted. See Declaration on the TRIPS Agreement and Public Health, November 14, 2001, WTO Doc. WT/MIN(01)/ DEC/2, paragraph $5(b)$. 
50 See US-JO FTA, supra n. 6, article 4.22.

51 Ibid., article 4.22,

footnote 10.52 Ibid.,

article 4.23(a).

53 Ibid., articles 4.24-4.28.

54 The right holder must prove that the infringer has engaged in the infringing activity "knowingly". In other words, the infringer must possess the intention to engage in the infringing activity.

55 See US-JO FTA, supra n. 6, article 4.24.

56 See Provisional Copyright Law No. (52) supra n. 29, article 49.

57 See US-JO FTA, supra n. 6, article 4.25.

58 See Provisional Copyright Law No. (52), supra n. 29, article 9.

59 See US-JO FTA, supra n. 6, article 4.25. The use of the term "predominant use" is unclear. For example, it is unclear whether $60 \%$ use of the tool for committing piracy suffices the US-JO FTA's requirement.

60 Ibid., article 4.26.

61 lbid., article 4.27.

62 See Provisional Copyright Law No. (52), supra n. 29, article 2.

63 See US-JO FTA, supra n. 6, article 4.28.

64 J.T. McCarthy, McCarthy's Desk Encyclopedia of Intellectual Property (2nd edn), Bureau of National Affairs, Washington DC, 1995. p. 32.

65 See Provisional Copyright Law No. (52), supra n. 26. 66 See US-JO FTA, supra n. 6, article 4.29.

67 See R. Abdelrahman, Copyright treaty comes into effect today, Jordan Times (April 27, 2004), at 2.

68 See C.S. Rugaber, US copyright groups recommend suspension of Russia's trade benefits, International Trade Reporter (BNA), 22 (February 17, 2005) 257 (stating that in addition to Russia and Singapore, US copyright groups said that dispute-settlement proceedings should be initiated against Jordan under the process set out in the FTA with Jordan, if certain outstanding intellectual property issues are not resolved). 